\title{
Developmentalism and the determinants of investment: an econometric exercise for Brazil in the 2000s
}

\author{
Carmem Feijo ${ }^{\dagger}$ \\ Julia de Medeiros Braga ${ }^{\ddagger}$ \\ Mariana Finello Corrêa
}

\begin{abstract}
The aim of this paper is twofold. At first, we briefly review the current debate in Brazil between the new-developmentalists and the social-developmentalists. Both groups assume that the investment is the main component of aggregate demand to explain growth. However, the key variable to determine demand for investment is different for each group. For the new-developmentalists, the key variable is the real exchange rate. For the second group, public investment and domestic mass consumption are the most relevant variables. Given this debate, our next step is to test econometric models that capture the determinants of investment in Brazil in the 2000s. We start with the investment function presented by Bhaduri and Marglin (1990) and add other variables according to the developmentalist debate. We found robust results that confirm the validity of Bhaduri and Marglin's hypothesis as well as the ones proposed by the new-developmentalists and the socialdevelopmentalists.
\end{abstract}

Keywords: new-developmentalism; social-developmentalism; investment; Brazil. JEL Classification: E22; O11

\footnotetext{
* The authors wish to thank the insightful comments of the anonymous referees to improve our paper. The usual caveats apply.

${ }^{\dagger}$ Full professor, Universidade Federal Fluminense, Cnpq researcher, e-mail: cbfeijo@gmail.com

¥ Associate professor, Universidade Federal Fluminense, e-mail: jbraga@id.uff.br

${ }^{\S} \mathrm{PhD}$ student at Universidade Federal Fluminense, e-mail: finello.mari@gmail.com
} 


\section{Introduction}

The recovery of the Brazilian economy in the mid-2000s, following the good performance of the current accounts during 2003-2007 as well as the rapid positive response after the international financial crisis in 2009 gave boost to the academic interest on the debate on developmentalism in Brazil. ${ }^{1}$ The recent domestic economic crisis has been reinforcing this interest as conventional economic policies are inept to deliver a sustainable way out to the current crisis. Biancarelli (2012) points out that the debate unfolds on two levels. On the theoretical level, a critical review has been conducted of some issues of the old developmentalism propositions. ${ }^{2}$ On the empirical level, the debate is focused on alternative economic policies to the neoliberal project of development. ${ }^{3}$ Academic works by BresserPereira (2006), Sicsú et al. (2005) and Bielschowsky (2014), among others, have gained prominence in this academic discussion. Following the intensification of the debate, Mollo and Amado (2015), for example, subdivided the new developmentalist positions into three groups: the new developmentalists (see for example Bresser-Pereira, 2006), the post-Keynesian developmentalists (see for example Sicsú et al., 2005) and the social developmentalists (see for example Bielschowsky, 2014). ${ }^{4}$

In this paper, we are interested in discussing the determinants of the investment in fixed capital in the 2000s in Brazil, according to the developmentalist debate. In this sense we will evaluate how developmentalists propositions help us to better understand the investment dynamics in Brazil between 1999 to $2013 .{ }^{5} \mathrm{We}$ will propose an econometric model to test the significance of the main variables that the new-developmentalist and the social-developmentalist group emphasize as the most relevant to explain the behavior of aggregate investment. Special emphasis is given to the importance of the real exchange rate and to public investment in explaining investment decisions. Thus, the main contribution of this paper is, based on the different agendas of economic policy proposed by the

\footnotetext{
${ }^{1}$ For a discussion about the concept of developmentalism, see Fonseca (2014).

${ }^{2}$ For a summary of the 'old developmentalist' approach, see Bresser-Pereira and Gala (2012, Table 1: Original developmental theory compared with structuralist macroeconomy of development, p. 31)

${ }^{3}$ See also Nassif and Feijo (2013) for a discussion about the new conventions of developmentalism.

${ }^{4}$ Social developmentalism presents other terminologies in the literature. See Calixtre et al. (2014, p.16)

5 We should remark that it is not our intention to propose an exhaustive debate about the developmentalist authors. We consider that, broadly speaking, both social and new developmentalists are post-Keynesian and heterodox institutionalists. For recent bibliography on the developmentalim see, for instance, Arestis and Baltar (2017), Carvalho and Rugitsky (2015), and Ribeiro et al. (2017). We thank the anonymous referee for suggesting these references.
} 
developmentalism debate in Brazil, to discuss the determinants of investment behavior in the 2000s.

Following this brief introduction, this paper is divided into four further sections. Section two analyzes the current developmentalist debate in Brazil. Section three briefly presents the evolution of the investment rate during the 2000s. Section four presents an econometric estimation of the investment in Brazil for the period 1999-2013 and the last section concludes the paper.

\section{The determinants of investment in the developmentalist debate in Brazil ${ }^{6}$}

The developmentalists share in common the theoretical references of the macroeconomics of Keynes and the Latin American structuralism. ${ }^{7}$ In particular, the developmentalists agree with the active role of aggregate demand in explaining economic growth, and among the components of aggregate demand investment in fixed assets is considered the driving force of this process. However, for each group within developmentalism, investment responds more strongly to a specific variable, i.e., each group elects a key variable to explain investment behavior. We will explore the differences between the new-developmentalists and the socialdevelopmentalists in order to specify our econometric model to explain the behavior of the investment in Brazil in the 2000s.

\subsection{New-developmentalism}

For the new-developmentalists, a country that has completed its industrialization process and reached a certain level of average income will have its long-term growth determined by the growth in aggregate demand, especially by the expansion of the autonomous components. According to this group, the main component of aggregate demand for a small open economy dependent on foreign savings is the demand for exports (Bresser-Pereira et al., 2015).

Based on Kalecki (1983, chapter 9), the new-developmentalists assume that the capital stock of an economy is determined by past investment decisions. These decisions, following Keynes's tradition (1936, chapters 12 and 17) in turn, depend primarily on two factors: profit opportunities as perceived through the gain of positive yields and the opportunity cost to invest in fixed assets.

\footnotetext{
${ }^{6}$ For a more detailed analysis about the recent developmentalist debate in Brazil see Corrêa and Feijó (2017).

${ }^{7}$ For bibliographical reference on Keynes and Latin American structuralism, see Bárcena and Prado (2016, p. 19, footnote 2)
} 
Given the importance of the foreign sector, the new-developmentalists distinguish two types of investment: one aimed at the domestic market and the other looking at the prospects of the external market. In the former, the key variable is domestic consumption and it depends on the growth rate of total wages. In the latter, the key variable is the growth of world demand and the income elasticity of exports of a country. Adherents to this theory conclude that for a small open economy dependent on foreign savings the potential growth rate is determined by the growth rate of exports. This is so because it is assumed that small open economies have a high external constraint to growth, which is only relaxed through the expansion of exports in the long-term (Bresser-Pereira et al., 2015).

Finally, the new-developmentalist assumes that there is a structural relationship between investment in fixed capital, technical progress and economic growth. The investment will respond to positive expectations in profit, which depend on expectations in the growth of demand and the opportunity cost of capital. Under optimistic expectations of growth in aggregate demand, investment will stimulate capital accumulation through the introduction of machinery and equipment at the technological frontier. Therefore, the incorporation of technical progress occurs through the introduction of new machinery to the stock of capital which increases productivity, which, in turn, reduces the unit cost of goods produced. That is to say, capital accumulation increases both the price and the nonprice competitiveness. Increased competitiveness promotes an increase in exports, which feeds back to the virtuous circle of growth, stimulating new investment and so on. The increased competitive capacity of the country would be maintained by this virtuous circle, where wage increases should follow the increase in productivity.

In short, for new-developmentalism, the investment rate depends directly on the aggregate demand, specifically investment opportunities facing the export sectors of tradable goods. The investment decisions of these sectors would be sensitive to changes in the real exchange rate, because depreciations in the exchange rate make investment decisions in these sectors more attractive. Therefore, for this group, the key variable to explain investment behavior is the real exchange rate, because of its positive effect to expand foreign markets for firms in the technological frontier, and the key economic policy is an active exchange rate policy. 


\subsection{Social developmentalism}

Bielschowsky's analysis (2014) presents the dynamics of investment according to the social-developmentalists. In his works, the author presents what the three main sources of expansion for the Brazilian economy would be that would guide the country to sustainable growth. He also offers two mechanisms that would increase the effects of these sources. The sources of expansion he presents are: the expansion of the market for mass consumption of goods and services; the availability of exploitable natural resources, and the expansion of economic and social infrastructure. The mechanisms that would enhance these sources are: the connection among firms and sectors through productive chains and the incorporation of technological innovation through investment.

In Bielschowsky (2014, p.124), the author details how to develop a growth model based on consumption and the production of mass consumption goods. The model assumes that the expansion of the market for mass consumption would occur with a change in the productive structure to meet the growing demand. The intensification of mass production would allow an increase in returns to scale and the introduction of technical progress, which, in turn, would allow real wage increases without pushing up inflation.

Castro (1990, p.373) presents the virtuous circle in which an increase in real wages would lead to an increase in investment, stimulated by the expansion of the internal market. According to him, there would be an 'intense exchange of stimuli' between wages and investment: therefore, the expansion in investment would entail the incorporation of new techniques and the introduction of new products. This would result in increased labor productivity and further space for wage increases in real terms.

Social-developmentalism also highlights the role of the public sector in boosting investment as implied by the third source of expansion. ${ }^{8}$ Investment in infrastructure would not only be responsible for the expansion on the part of the investment, but also act as a kind of "spearhead". That is to say, the initial public investment in infrastructure would lead to new private investment that would follow given the new conditions created by both better investment opportunities and positive expectations.

In short, for social-developmentalism, the operation of the domestic market is the main driver of expansion in the Brazilian economy, assuming that this expansion stimulates the production of mass consumer goods. In this strategy,

\footnotetext{
${ }^{8}$ See Bielschowsky and Mussi (2006), for example. See also next footnote.
} 
income distribution policies, the real valuation of the minimum wage and banking inclusion would all have a very positive effect on strengthening the economic dynamism. Investment in social infrastructure, that is to say, public health, sanitation, and so on, should also be combined with this strategy of boosting domestic market of mass consumer goods. ${ }^{9}$ Thus, an income distribution policy would not only give access for the inclusion of the poor populations in the consumption of private goods, but also give access to assets for collective consumption.

\section{Investment in Brazil in the 2000s: an overview}

Our analysis starts in 1999, when the current macroeconomic policy regime, based on inflation targeting, primary fiscal surplus and flexible exchange rate was implemented. GDP grew 2.4\% on average per year during the period 1999-2016, followed by a $2.3 \%$ average growth of domestic absorption. Exports and imports grew respectively $5.3 \%$ and $3.3 \%$ on average during the same period (Figure 1). Table 1 presents the growth rates for the main components of aggregate demand. Considering 1999-2016, gross capital formation presented the lowest rate of growth on average (1.6\% per year), compared with the other variables in the same period.

Growth rates varied significantly throughout the 1999-2016 period. At the beginning of the 2000s (1999-2002), the main driver of growth came from the foreign sector, where exports grew on average $8.5 \%$ per year. Gross capital formation growth rate was negative and domestic absorption grew $1.1 \%$ on average.

The expansion of world trade in the following years allowed for an acceleration in the rates of growth of domestic absorption, which expanded on

\footnotetext{
${ }^{9}$ The perception of the importance of investment in social infrastructure as important source to boost economic growth constitutes one of the most innovative proposals of this group. The term social infrastructure (Biancarelli and Rossi, 2013, p.150) or public consumption (Kerstenetzky, 2016, p.37) includes investments in education, health, public transport, sanitation, and other activities that affect the living conditions of the population. For Biancarelli and Rossi (2013, p.150-151) the investment in social infrastructure not only increases aggregate investment, but also reduces the social deficit and generates indirect impacts which positively affects productivity in the long-term. The main indirect impacts are increased labor productivity through the improvement in the living conditions of workers by increasing the quality of education and health. A better qualified work force would, in turn, increase non-price competitiveness gains. Furthermore, Kerstenetzky (2012, p.46-47; 2016) points out that the expansion in spending on public consumption would generate direct economic impacts through the increase in public employment in the social services segment. This would impact directly on aggregate consumption and, also act as a mechanism for consumption smoothing the economic cycle.
} 
average $4.4 \%$ per year, and gross capital formation presented the highest rate of growth: $6.1 \%$ on average per year during the period 2003-2008. During this period of external bonanza ${ }^{10}$, domestic demand was largely met with increased imports, which grew $11.7 \%$ on average.

This period of higher dynamism was short lived, though, because of the international financial crisis in 2008 that dramatically changed the foreign economic context. Brazilian authorities managed to implement countercyclical policies in the aftermath of the international financial crisis, and the economy recovered well in 2010, growing over 7 \% that year. However, since 2011, Brazilian economic growth rate has been following a stop-and-go pattern, and gross capital formation has started to decelerate. In 2014 the economy stagnated and dived into a severe recession in the following years, registering an accumulated decrease of $7.2 \%$ in 2015 and 2016.

Figure 1. Average growth rates of GDP, domestic absorption, exports and imports: selected periods- 1999-2016

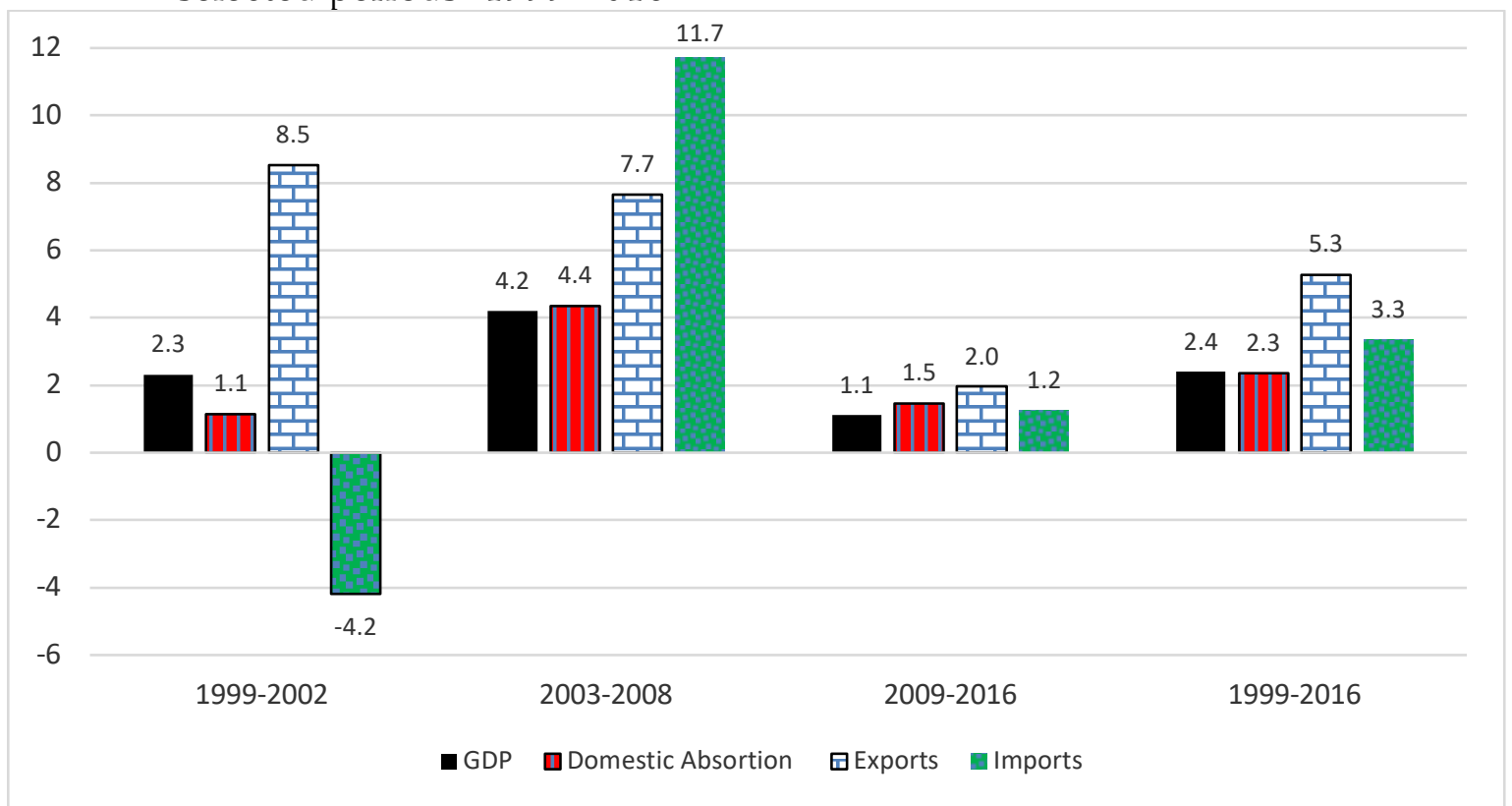

Source: IBGE (2019)

\footnotetext{
${ }^{10}$ It should be remarked that the relation between international liquidity and investment is also important to explain the evolution of capital accumulation in physical capital in the period of 'bonanaza'. For an empirical investigation on this relevance in developing countries see Torres and Resende (2015).
} 
Table 1. Growth rate of GDP and main components of aggregate demand (selected periods, 1999-2016)

\begin{tabular}{l|c|c|c|c|c|c}
\cline { 2 - 6 } & GDP & $\begin{array}{c}\text { Private } \\
\text { Consumption }\end{array}$ & $\begin{array}{c}\text { Public } \\
\text { Consumption }\end{array}$ & $\begin{array}{c}\text { Gross } \\
\text { Capital } \\
\text { Formation }\end{array}$ & Exports & Imports \\
\hline $\mathbf{1 9 9 9 - 2 0 0 2}$ & 2.3 & 1.6 & 2.0 & -1.2 & 8.5 & -4.2 \\
\hline $\mathbf{2 0 0 3 - 2 0 0 8}$ & 4.2 & 4.3 & 2.9 & 6.1 & 7.7 & 11.7 \\
\hline $\mathbf{2 0 0 9 - 2 0 1 6}$ & 1.1 & 2.0 & 1.5 & -0.3 & 2.0 & 1.2 \\
\hline $\mathbf{1 9 9 9 - 2 0 1 6}$ & 2.4 & 2.7 & 2.1 & 1.6 & 5.3 & 3.3 \\
\hline
\end{tabular}

Source: IBGE (2019)

Figure 2 shows the evolution of the gross capital formation, the basic interest rate and the real exchange rate since 1999. During the first period, 19992002 , the investment rate was $18.8 \%$ on average and the economic growth rate was $2.3 \%$ per year. In this period, the highest level of the basic interest rate was recorded, and the real exchange rate registered the overshooting observed during the second half of 2002 due to speculations on the result of the presidential election that happened that year.

In the next period of higher GDP growth, the investment rate showed a consistent growth trend from 2005 onwards, and the basic interest rate started to decrease. The expansion of world trade, the boom in the price of commodities exported by Brazil, and the boom of capital inflows, on the other hand, contributed to a continuous appreciation of the real exchange rate. The greater impact of the recovery in the investment rate is felt in the next period (2009-2016), since, though being a period of decelerating GDP growth rates, it captures the lagged response of the investment in fixed assets that had started in the previous period. Finally, it should be remarked that during the second mandate of President Lula da Silva (2007-2010) growth became an explicit concern of economic policy, as seen with the launching of a governmental plan to stimulate investment: the PAC - Política de Aceleração do Crescimento (Policy for Growth Acceleration). In the first mandate of President Rousseff (2011-2014), another attempt to promote growth was made with the launching of the Plano Brasil Maior (in April 2013. In addition to those, a policy of fiscal stimulus to private firms, mainly in the industrial sector, was implemented aiming at increasing the profit rate of firms. This policy did not produce the expected result as the positive outlook of increased demand was not strong enough to induce investment decisions. ${ }^{11}$ One of the main reasons why such a policy might not have worked is because the main pillars of the macroeconomic

${ }^{11}$ It should be remarked that the domestic political crisis in 2015 strongly influenced negatively economic decisions. 
regime - inflation targeting and primary fiscal surplus - were left untouched, constraining aggregate demand growth.

Figure 2. Investment rate, basic nominal interest rate (31/12) and real exchange rate (1999-2016)

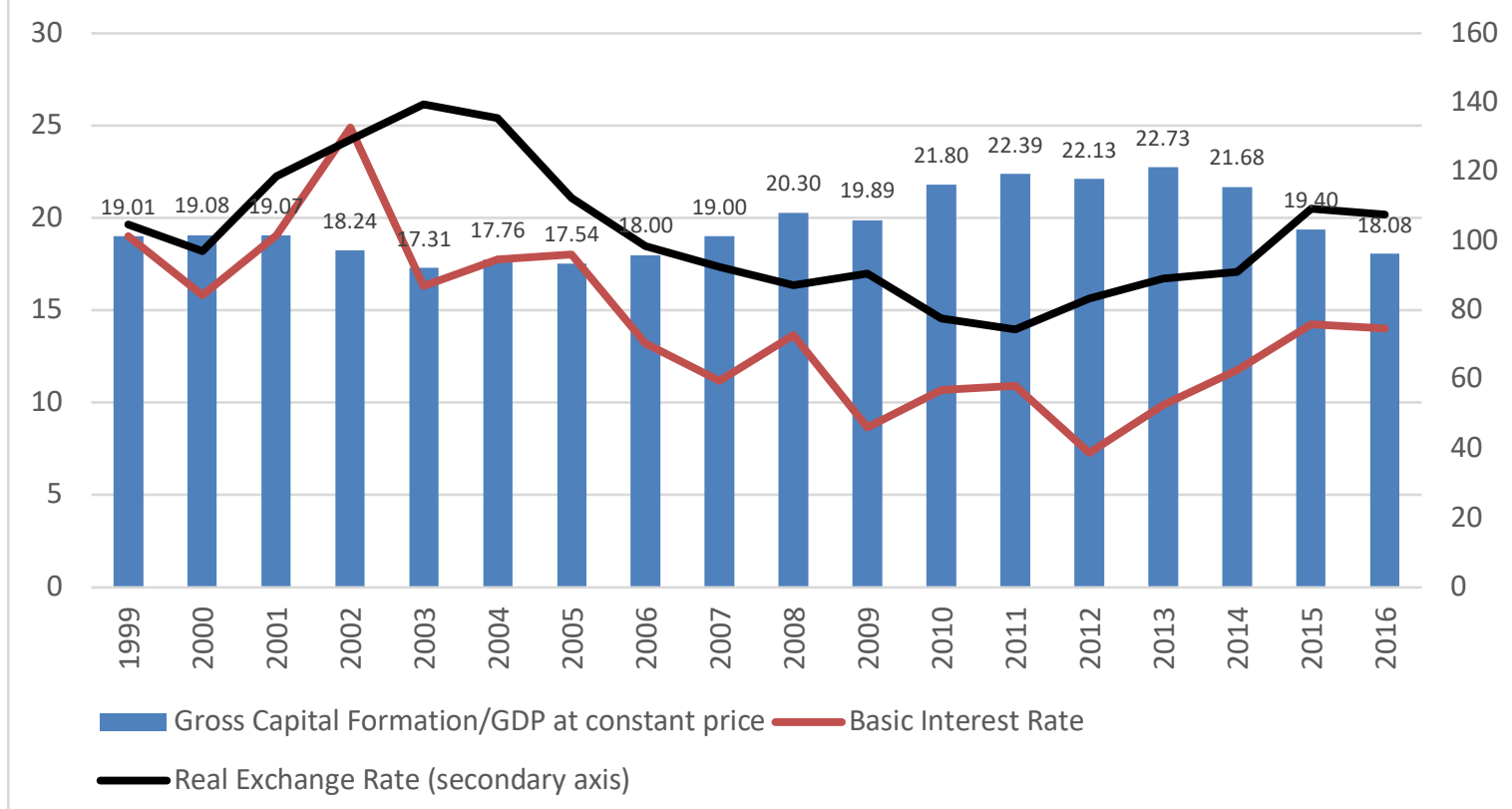

Source: IBGE (2019) and Banco Central do Brasil (2019).

In sum, GDP growth rates were relatively unstable during the period of our study and the macroeconomic policy did not favor capital accumulation in Brazil. Actually, domestic interest rates were kept at persistent high levels (although decreasing in some years), and the real exchange rate was volatile and showed a trend to appreciate. High interest rates, on the one hand, signaled too high of a floor for productive investment to compete with other financial applications. On the other hand, the high vulnerability of Brazilian economy to external shocks impacted the real exchange rate, which tended to appreciate, discouraging exports, and increasing labor unit costs. In such an environment, the degree of confidence in expectations that would support long-term commitment of resources is jeopardized. 


\section{The determinants of investment: an econometric model for Brazil in the 2000s}

\subsection{The theoretical specification}

The aim of this section is to present the specification of an econometric model to describe the determinants of the investment in physical capital in Brazil in the 2000s, taking into account the two developmentalist strategies discussed in Section 2. To achieve this goal, we will start with the theoretical framework following the contribution of Bhaduri and Marglin (1990).

In Bhaduri and Marglin (1990, p.380), investment can be explained by the degree of capacity utilization $(u)$ and the profit-share $(h)$. These two variables allow the clear separation between the 'demand side' and 'supply side' impacts of income distribution on investment. An income distribution from profit to wages (an increase in real wages), would lead to an increase in household consumption, which would increase the demand and affect capacity utilization positively, through acceleration effect would impact on investment ('demand side impact'). On the other hand, an income distribution from wages to profits (decrease of real wage), would impact on the investment through reduction off firm's costs ('supply side impact').

For the new-developmentalists, it is expected that the share of profits $(h)$ should be more important to explain investment decisions. For the socialdevelopmentalists, it is expected that the rate of capacity utilization $(u)$ would be more important. ${ }^{12}$ Formally, following Bhaduri and Marglin (1990, p.380), we can write the investment function (I):

$$
I=f(h, u)
$$

It is worth noting that this specification extended the analytical possibilities of the model regarding older versions of the neo-Kaleckian model for the determinants of investment. In Bhaduri and Marglin's specification either a stagnationist or an exhilarationist result may occur. In the older versions, periods of economic stagnation would be the result of a fall in the wage share, which would lead to a contraction in the aggregate consumption negatively affecting capital

${ }_{12}$ It is worth mentioning that the profit share is also a relevant argument for the social developmentalists, as they recognize the importance of income distribution in the investment function. However, they assume that an increase in the profit share will contribute with a negative signal in the investment function. 
accumulation and economic growth. ${ }^{13}$ In Bhaduri and Marglin's specification, stagnation is no longer the only result because their model allowed for the possibility of the investment to react positively to a fall in the wage share (an increase in the profit share in income).

Our model for Brazilian economy will initially consider the specification of the investment function as proposed in Equation (1) and will add other variables following the recent developmentalist debate.

For the new-developmentalist, the real exchange rate is the strategic variable to explain the investment decision because a competitive exchange rate would allow firms that are non-commodity producers to compete in the foreign market, ${ }^{14}$ since they are in the frontier of the technological process of production. ${ }^{15}$

Oreiro et al. (2015, p.241) present an econometric model based on Bhaduri and Marglin (1990), adding the real exchange rate $(e)$ in their specification. The authors argue that the exchange rate has two different impacts on investment. On the one hand, the exchange rate can be seen as having a positive impact on capital accumulation, because when it is kept at a competitive level, it gives domestic noncommodity producer firms access to foreign markets. A competitive real exchange rate implies that the profitability of export firms would be sustained, increasing their capacity to accumulate funds, and thus to invest. On the other hand, the exchange rate impacts the investment decision as a cost because a depreciation will increase the cost of imported equipment and inputs.

The authors assume that the best way to capture these two influences on the investment function is to consider the real exchange rate in level and also in a quadratic form. This implies to assume that the relationship between the growth rate of capital accumulation and the real exchange rate is non-linear. According to the authors: "It is more reasonable to think that for very low levels of real exchange rate, the competitiveness and profitability of tradable sectors are also very low, discouraging investment in new machines and equipment, as a result the growth rate of capital stock is also low. For very high levels of real exchange rate, however,

\footnotetext{
${ }^{13}$ It should be remarked that an initial criticism to Bhaduri and Marglin's seminal work was based on the use of the realized profit rate as an argument in the investment function. For a discussion on this topic, see Rowthorn (1981); Dutt (1984); Taylor (1985), among others. See also Hein (2014, Chapter 6), Bertella (2007) and Blecker (2002) for more information on the differences between neoKaleckian and post-Kaleckian investment function.

${ }^{14}$ This reasoning, that implies that a competitive exchange rate would also increase the profit share of non-commodity producers' firms, shows the importance of the profit share in the investment function due to its link to the exchange rate.

${ }^{15}$ See Dos Santos et al. (2016), Feijo et al. (2016) and Luporini and Alves (2010), who also use the real exchange rate in their investment functions.
} 
the cost of investment will be very high due to high prices of imported machines and equipment. As a result, the growth rate of capital stock will again be low. In this case, for intermediate levels of real exchange rate competitiveness, profitability and the cost of investment will be at reasonable levels in order to induce a high rate of capital accumulation" (Oreiro et al., 2015, p.242).

Therefore, incorporating both effects of the real exchange rate in our model we can write

$$
I=f\left(h, u, e, e^{2}\right)
$$

For the social- developmentalists, the investment in economic and social infrastructure constitutes an important component in determining the investment function. The assumption is that the investment in infrastructure drives private investments. Considering that investment in infrastructure is held by the public sector, this variable will be included in our specification as $\left(i_{p}\right)$. So, we can write ${ }^{16}$

$$
I=f\left(h, u, e, e^{2}, i_{p}\right)
$$

Finally, we complete our specification considering the role of the real interest rate in the investment function. The post-Keynesian developmentalists (Sicsú et al., 2005) this is a key variable to explain the investment rate. Following Kalecki's (1937) principle of increasing risk, the level of the interest rate put a limit to the indebtedness of the firm ${ }^{17}$. In this sense, the interest rate is interpreted as a financial cost to firms, which would have a negative impact on investment.

The investment function to be estimated is as follows, where $(r)$ is the real interest rate:

$$
I=f\left(h, u, e, e^{2}, i_{p}, r\right)
$$

\subsection{Methodology}

Our estimates use monthly data from July 1999 to December 2013, totalizing 174 observations. The dependent variable (investment) is represented by the apparent consumption of capital goods, following Dos Santos et al. (2016,

\footnotetext{
${ }^{16}$ See Dos Santos et al. (2016), Luporini and Alves (2010) and Dos Santos and Pires (2007; 2009) who also use this variable in their estimations.

17 "Furthermore, applying Kalecki's (1937) 'principle of increasing risk', changes in the rate of interest have an impact on retained profits and thus on the willingness and the ability of firms to invest in capital stock." (Hein, 2014, p.370).
} 
p.206). Appendix 1 presents the list of the variables and their corresponding sources, as well as some remarks about the construction of the statistics used.

To estimate the model, we started with the unit root tests (Table A. 2 in the Appendix) that showed that part of the series has a unit root in level. We define the following variables in log: apparent consumption of capital goods the real effective exchange rate in level $(e)$ and in the quadratic form $\left(e^{2}\right)$ and public investments $\left(i_{p}\right)$. All of them are I (1). The degree of capacity utilization $(u)$, the profit share $(h)$ and real interest rate $(r)$ are $\mathrm{I}(0)^{18}$.

Given the results of the unit root tests, we followed two modelling strategies. In the first, the series were included in the model as growth rates. In the second, the series were maintained in level and a regression was estimated from the cointegration dynamic least squares estimator, the so-called DOLS (Stock and Watson, 1993). This cointegration regression model allows us to use the set of variables in I (1) and I (0).

The cointegration vector between the $m$ sets I (1) $\left(\mathrm{y}_{1, \mathrm{t}}, \mathrm{y}_{2, \mathrm{t}}, \ldots\right)$ can be normalized in order to allow that the variable $y_{1, t}$, that is, the apparent consumption of capital goods, to be expressed as a function of other variables I (1), gathered in vector $\mathrm{Y}^{*}=\left(\mathrm{y}_{2, t}, \mathrm{y}_{3, t}, \ldots \mathrm{y}_{\mathrm{m}, \mathrm{t}}\right)$, of size $m-1$ and of the variables $\mathrm{I}(0)$, gathered in vector $\mathrm{X}$ :

$$
y_{1}=\mathbf{X} \beta+\mathbf{Y} * \boldsymbol{\eta}+\mathbf{v}
$$

To avoid an endogeneity bias problem, Stock and Watson (1993) suggest adding leads and lags of the first difference of the $\mathrm{Y}^{*}$ vector in the cointegration regression removing the effect of the short-term dynamics of that $v$ error has on the estimates

$$
\boldsymbol{y}_{\mathbf{1}}=\mathbf{X} \boldsymbol{\beta}+\mathbf{Y} * \boldsymbol{\eta}+\sum_{j=-p}^{p} \Delta \boldsymbol{Y}_{-j}^{*} \boldsymbol{\gamma}_{\boldsymbol{j}}+\boldsymbol{v}
$$

The DOLS estimator is consistent, efficient and asymptotically normally distributed.

\subsection{Results}

The results are compiled in Table 2. First, we ran the specification of the investment function by Bhaduri and Marglin (1990, p. 380), where the investment

\footnotetext{
${ }^{18}$ The series I, $i_{p}, h$ and $u$ were seasonally adjusted by the method Census X-12 (EViews 8).
} 
is a function of the profit share $(h)$ and the capacity utilization $(u)$, as in Equation (7).

$$
\log I=c+\alpha u+\beta h
$$

For this first regression we used the series in growth rate to avoid the unit root problem and added a moving average - MA (1) - to exclude possible autocorrelation problems (Table A.2 and A.3 in the Appendix). Since the regression presented heteroskedastic errors (Table A.4 in the Appendix), it was run again with the covariance matrix of the residues estimated via the White estimator to solve this problem.

Table 2. Model 1 results (Method: least squares, Dependent variable: $\log I$ )

\begin{tabular}{c|c|c|c|c|}
\hline Variable & Coefficient & Std. Error & t-Statistics & Prob \\
\hline$h$ & 0,21 & 0,039 & 5,436581 & 0,00 \\
$u$ & 3,64 & 0,26 & 1,415443 & 0,00 \\
$c$ & $-285,22$ & 2512718 & $-1,135098$ & 0,00 \\
MA (1) & $-0,64$ & 0,06 & $-1,017841$ & 0,00 \\
\hline R-squared & 0,66 & & \\
Adjusted R- & 0,66 & & \\
squared & 1123204 & & \\
F-statistic & & & \\
Prob(F- \\
statistic) & 0,00 & & \\
Durbin-Watson & 2,0655002 & & \\
stat & & & \\
Source: Authors' own elaboration.
\end{tabular}

Our estimation of Equation (7) shows that all coefficients were significant. The sensibility of the apparent consumption of capital goods to variations in the increase in the degree of capacity utilization $(u)$ was greater than the profit share (h). ${ }^{19}$ Changes in $u$ impact 16.9 times more investments in fixed capital than variations in $h$. This result does not change if we take the logarithm of all the variables in the model, since all variables are in rate of change, therefore coefficients are actually elasticities.

To implement the other econometric models, we used the proxy for the investment rate in level (definition in the Appendix). Therefore, we started running the cointegration test Phillips-Ouliaris for the series in level. The test indicates the rejection of the hypothesis that the series are not cointegrated (Tables A.5 and A.6

\footnotetext{
${ }^{19}$ For a discussion about the demand regime in Brazil in the 2000s see, for instance, Araújo and Gala (2012).
} 
in the Appendix), validating the choice of estimating our investment function using cointegration.

The next step was to add more variables to Equation (7): the log of the real effective exchange rate (in level and in the quadratic form $-\log e$ and $\log e^{2}$ ), the real interest rate $(r)$, and the log of public investment $\left(\log i_{p}\right) \cdot{ }^{20} \mathrm{We}$ also added the trend term. Thus, the new regression with variables in level reads as follows:

$$
\log I=c+\alpha u+\beta h-\gamma \log e+\delta \log e^{2}-\eta r+\theta \log I p+\varepsilon \text { trend }
$$

We ran Equation (8) in three different ways (results in Table 3). In all models (2, 3 and 4), the following variables were regressed: the degree of capacity utilization $(u)$, the profit-share $(h)$, the real exchange rate - in level $(e)$ and in the quadratic form $\left(e^{2}\right)$ and the real interest rate $(t)$. The public investment $\left(i_{p}\right)$ was not included in model 2, but a trend variable was. In model 3 we ran Equation (8), and in model 4 we excluded the trend variable to test its effect on the public investment.

To assure there is no endogeneity bias, we use a Block Exogeneity test (Wald). A VAR(4) was chosen so that residues were not autocorrelated. The results are showed in the table 3 , indicating the non-rejection of the elimination of investment at all equations, showing that all the variables can be considered as exogenous to the investment equation.

Table 3. VAR Granger Causality/Block Exogeneity Wald Tests

\begin{tabular}{lccc}
\hline Sample: 1999M07 2013M12 & Chi-sq & df & Prob. \\
\hline Variable excluded: LOGFBKF & 2,19 & 4 & 0,70 \\
Dependent variable: LOGUS\$ & 2,25 & 4 & 0,69 \\
Dependent variable: LOGUS\$_2 & 1,85 & 4 & 0,76 \\
Dependent variable: H_SA & 2,18 & 4 & 0,70 \\
Dependent variable: Z_SA & 3,84 & 4 & 0,43 \\
Dependent variable: R & & &
\end{tabular}
${ }^{20}$ The public investment series doesn't include state-owned enterprises (or partial state owned like
Petrobras). A full description of the data can be found in Dos Santos et all (2012). 
Table 4. Cointegration results

\begin{tabular}{|c|c|c|c|c|c|c|c|c|}
\hline MODEL & c & $u$ & $h$ & LOGe & \multicolumn{2}{|c|}{$\mathrm{LOGe}^{2}$} & LOGi $i_{P}$ & Trend \\
\hline Model 2 & $\begin{array}{c}\mathbf{9 , 6 1} \\
{[3,39]} \\
(0,00)\end{array}$ & $\begin{array}{c}3,56 \\
{[4,41]} \\
(0,00)\end{array}$ & $\begin{array}{c}1,39 \\
{[3,20]} \\
(0,00)\end{array}$ & $\begin{array}{c}-\mathbf{3}, \mathbf{4 2} \\
{[-3,03]}\end{array}$ & $\begin{array}{c}\mathbf{0 , 3 3} \\
{[2,72]}\end{array}$ & $\begin{array}{c}-1, \\
{[-2,} \\
(0,\end{array}$ & & $\begin{array}{c}\mathbf{0 , 0 0} \\
{[4,83]} \\
(0,00)\end{array}$ \\
\hline Model 3 & $\begin{array}{c}\mathbf{9 , 8 2} \\
{[3,21]} \\
(0,00) \\
\end{array}$ & $\begin{array}{c}3,31 \\
{[4,32]} \\
(0,00) \\
\end{array}$ & $\begin{array}{c}\mathbf{0 , 8 6} \\
{[2,05]} \\
(0,04) \\
\end{array}$ & $\begin{array}{c}-3,57 \\
{[-3,09]} \\
(0,00) \\
\end{array}$ & $\begin{array}{r}\mathbf{0 , 3} \\
{[2,8} \\
(0,0 \\
\end{array}$ & $\begin{array}{l}-1,26 \\
{[-3,5]} \\
(0,00) \\
\end{array}$ & $\begin{array}{c}\mathbf{0 , 1 3} \\
{[1,95]} \\
(0,05) \\
\end{array}$ & $\begin{array}{c}\mathbf{0 , 0 0} \\
{[0,65]} \\
(0,52) \\
\end{array}$ \\
\hline Model 4 & $\begin{array}{c}9, \mathbf{4 5} \\
{[3,15]} \\
(0,00)\end{array}$ & $\begin{array}{c}3,30 \\
{[4,32]} \\
(0,00)\end{array}$ & $\begin{array}{c}\mathbf{0 , 9 2} \\
{[2,22]} \\
(0,03)\end{array}$ & $\begin{array}{c}-3,45 \\
{[-3,03]} \\
(0,00)\end{array}$ & $\begin{array}{r}\mathbf{0 , 3} \\
{[2,8} \\
(0,0\end{array}$ & \begin{tabular}{|c|}
$-1,34$ \\
{$[-4,14]$} \\
$(0,00)$
\end{tabular} & \begin{tabular}{l|c}
,34 & $\mathbf{0 , 1 6}$ \\
14] & {$[5,16]$} \\
$00)$ & $(0,00)$ \\
\end{tabular} & \\
\hline \multicolumn{9}{|c|}{ STATISTICS } \\
\hline Model & $\begin{array}{c}\text { R- } \\
\text { squared }\end{array}$ & $\begin{array}{l}\text { Adjusted } \\
\text { R-squared }\end{array}$ & $\begin{array}{c}\text { S.E. of } \\
\text { regression }\end{array}$ & $\begin{array}{r}\text { Mea } \\
\text { depe } \\
\text { var }\end{array}$ & & $\begin{array}{l}\text { S.D. } \\
\text { depend } \\
\text { var }\end{array}$ & $\begin{array}{c}\text { Sum } \\
\text { squared } \\
\text { resid }\end{array}$ & $\begin{array}{l}\text { Long- } \\
\text { run var }\end{array}$ \\
\hline Model 2 & 0.95 & 0,95 & 0,06 & 4,3 & & 0,27 & 0,56 & 0,001 \\
\hline Model & 0,94 & 0,94 & 0,066 & 4,30 & & 0,27 & 0,7 & 0,01 \\
\hline Model 4 & 0,94 & 0,94 & 0,066 & 4,30 & & 0,27 & 0,71 & 0.01 \\
\hline
\end{tabular}

Source: Authors' own elaboration. Note: $t$ statistics in brackets; $p$-value in parentheses.

A first observation is that all coefficients in the three models were significant, considering a 5\% significance level. Another important result is that, in the three specifications, the degree of capacity utilization is more important than profit share to positively explain aggregate investment. ${ }^{21}$ If we consider that the measure of the degree of capacity utilization embodies some anticipation about the behavior of aggregate demand, we can say that this result suggests that the expectation of an increase in aggregate demand is the most important variable to explain a firm's decision to invest in capital expansion. It should be mentioned that during the period of our analysis (1999-2013), the domestic market expanded significantly due to improvements in income distribution and credit expansion to households. $^{22}$

\footnotetext{
21 Since the degree of capacity utilization and profit share are relative values, the correct interpretation (in Model 2, for instance) of the coefficients is the following: investments would increase $3.57 \%$ for each rise of one percentage point of the degree of capacity utilization, if all other variables were constant. In the same way, investments increase $1.39 \%$ for each rise of one percentage point of the degree of profit share, if all other variables were constant. Notice that if we estimate the models with these variables in logarithm the magnitude of the difference remains approximately the same (for model 2, for instance, the elasticity of the degree of capacity utilization would be $2.94 \%$, while for profit share would be $0.55 \%$, so the difference between them would be approximately 2,0 ).

${ }^{22}$ The results corroborate Ferrari Filho and Fonseca (2013), that argues that although the adoption of export-led or profit-led standards, as proposed by new-developmentalists, are technically "viable", could compromise the incipient results, in recent years, of income distribution. Therefore, a virtuous long-term trajectory will depend on the articulation between the triggered variable
} 
Considering the real exchange rate, the coefficient of the level of the real exchange rate $(e)$, which captures the cost effect of the currency in real terms on investment, is the most relevant variable to negatively explain aggregate investment. Indeed, considering for instance model 2, the elasticity of the real exchange rate in level is -3.42 , and in the quadratic form is 0.33 . This result is consistent with the current configuration of the Brazilian capital goods sector, given its dependence on imports of machinery and equipment. ${ }^{23,24}$ It should be noted also that the coefficients of the real exchange rate in both specifications ( $e$ and $e^{2}$ ) change relatively little when comparing the results of the three models.

As expected, the real interest rate has a negative impact on the apparent consumption of capital goods. This result can be interpreted in several ways: for instance, it suggests that firms are dependent on loans to invest, and/or that decisions to invest are sensitive to the opportunity costs of investment. It's important to note that the coefficient estimated (-1.069\%, in model 2 for instance) is a reaction to a change in a one point of the real interest rate and not $1 \%$, since there is no logarithm transformation in the real rate of interest series. Considering a mean of $3 \%$ in 2013 , a reaction of a fall of $1 \%$ of the real interest rate would be a rise of only $0.032 \%$ in investment (in model 2 ).

In model 3 , with public investment represented by $i_{p}$ and the trend variable, it was observed that the trend was not significant. This result led us to run model 4 , in which the trend component was excluded, and the regression was run only with the intercept. Model 4 reveals another interesting result of our estimate that confirms the importance of public investment in explaining aggregate investment. Model 4 also shows that the significance of the coefficients of public investment $\left(i_{p}\right)$, the profit share $(h)$ and the real interest rate $(r)$ were increased in relation to model 3. Finally, we should mention that even considering that the proxy used to capture the impact of public investment was not the best one, because the $i_{p}$ series also includes public expenditure in new machinery and equipment (see Dos Santos

(wages) and other components of aggregate demand, especially investment. Authors suggests a set of economic policy to allow this articulation to success.

${ }^{23}$ Gala and Araújo (2012) consider that Brazilian economy growth pattern is profit-led, mainly because of the external sector. Therefore, they argue that a currency devaluation has expansionary effects. There is no direct estimation, however, of the impact of the exchange rate on an investment function, but only on the net exportation.

${ }^{24}$ According to the National Confederation of Industry, the penetration coefficient of machinery and equipment increased from $25.2 \%$ in the $4^{\text {th }}$ quarter of 1996 to $36.4 \%$ in the $2^{\text {nd }}$ quarter 2015. 
et al., 2012), we should observe that the larger part of public investment is in civil construction. ${ }^{25}$

\section{Concluding Remarks}

In this paper, inspired by the developmentalist debate in Brazil, we run different versions of the investment function originally presented by Bhaduri and Marglin (1990), adding key variables to capture the arguments presented by the new-developmentalist and the social-developmentalists.

In all econometric versions tested, we found that the degree of capacity utilization greatly explained investment in fixed capital positively. The profit share was significant, but of less importance. Assuming that the degree of capacity utilization embodies some anticipation about the behavior of aggregate demand, this result suggests that the expectation of an increase in aggregate demand are the most important variable to explain a firm's decision to invest in capital expansion.

Considering the new-developmentalist argument, we included the real exchange rate in level and in the quadratic form to test their effect on investment. We observed that the impact of a devaluation of the real exchange rate would have a much greater negative impact on investment (captured by the variable in level) than a positive effect (captured by the variable in the quadratic form). Therefore, we concluded that the cost effect of a real devaluation on investment in fixed capital far exceeds the competitive effect on it. Thus, the overall effect of a devaluation on investment in capital goods is negative. This might be seen as a curious finding that the effect of the appreciation of the domestic currency against the dollar is to stimulate private investment by lowering the cost of imported inputs rather than to depress it because Brazilian products are then more expensive to foreigners

Therefore, our econometric exercise confirms that the real exchange rate is one of the most important variables to explain investment, as argue by the newdevelopmentalists, but we also found that the negative effect of the real exchange rate is more important than the positive effect to explain investment. Actually, the negative impact of the real exchange rate is much higher than the real interest rate.

Considering the social-developmentalist argument, we included public investment in two models. In the econometric specification including the public investment we observed that the importance of this variable is increased when we

${ }^{25}$ For example, the average share of gross fixed capital formation in civil construction between 1970 and 2005 was $79.31 \%$ of the total gross fixed capital formation by the public administration. 
exclude the trend component, which loses significance. This result allows us to suggest that public investment in infrastructure makes private expectations converge and induces investment in capital goods.

\section{References}

Araujo, E., \& Gala, P. (2012). Regimes de crescimento econômico no Brasil: evidências empíricas e implicações de política. Estudos Avançados, 2675), 41-56. https://doi.org/10.1590/s0103-40142012000200004

Arestis, P., \& Baltar, C. T. (2017). Income distribution, productivity and economic growth: Empirical evidence in the case of Brazil. In C. B. P. Arestis \& D. Prates (Eds.), The Brazilian Economy since the Great Financial Crisis of 2007/2008 (pp. 191-217). Basingstoke: Palgrave Macmillan. https://doi.org/10.1007/978-3-319-64885-9_8

Brasil, B. C. do. (2019). Sistema Gerenciador de Series Temporais (11752). Brasilia: Banco Central do Brasil. Retrieved from https://www3.bcb.gov.br/sgspub/localizarseries/localizarSeries.do?meth od=prepararTelaLocalizarSeries. Accessed on February 15 ${ }^{\text {th }}, 2019$.

Bárcena, A., \& Prado, A. (2016). Neostructuralism and heterodox thinking in Latin America and the Caribbean in the early twenty-first century. Santiago: UN ECLAC books.

Bastos, E. K. X. (2012). Distribuição funcional da renda no Brasil: estimativas anuais e construção de uma série trimestral (Texto para discussão do IPEA No. 1702). Brasilia. Available at http://www.ipea.gov.br/agencia/images/stories/PDFs /TDs/td_1702.pdf. Accessed on February 14 ${ }^{\text {th }}, 2019$.

Bertella, M. A. (2007). Modelos de crescimento kaleckianos: uma apreciação. Revista de Economia Política, 27(2), 209-220. https://doi.org/10.1590/S0101-31572007000200004

Bhaduri, A., \& Marglin, S. (1990). Unemployment and the real wage: the economic basis for contesting political ideologies. Cambridge Joumal of Economics, 14(4), 375-393. https://doi.org/10.1093/oxfordjournals.cje.a035141

Biancareli, A. M. (2012). Economia, sociedade e desenvolvimento, 20 anos: notas de apresentação. Economia e Sociedade, 21(spe), 723-727. https://doi.org/10.1590/S0104-06182012000400001 
Biancarelli, A., \& Rossi, L. (2013). A política macroeconômica em uma estratégia social desenvolvimentista. In A. Fagnani \& E. Fonseca (Eds.), Políticas sociais, desenvolvimento e cidadania - Economia, distribuição da renda e mercado de trabalho (pp. 147-166). São Paulo: Fundação Perseu Abramo.

Bielschowsky, R. (2014). Estratégia de desenvolvimento e as três frentes de expansão no brasil: um desenho conceitual. In A. Calixtre, A. Biancarelli, \& M. Cintra (Eds.), Presente e Futuro do Desenvolvimento Brasileiro (pp. 115-133). Brasília: IPEA.

Bielschowsky, R., \& Mussi, C. (2006). El pensamiento desarrollista en Brasil: 19301964 y anotaciones sobre 1964-2005. In R. Cave \& R. Gladys (Eds.), Brasil y Chile: una mirada hacia America Latina (pp. 15-62). Santiago: RIL Editores. Retrieved from http://repositorio.uchile.cl/handle/2250/123778

Blecker, R. (2002). Demand, distribution, and growth in neo-Kaleckian macro models. In M. Setterfield (Ed.), The Economics of Demand-Led Growth: Challenging the Supply-Side

Bresser-Pereira, L. C. (2006). O novo desenvolvimentismo e a ortodoxia convencional. Revista São Paulo Em Perspectiva, 20(3), 5-24. Retrieved from http://produtos.seade.govj.br/produtos/spp/v20n03/v20n03_01.pdf

Bresser-Pereira, L. and Gala, F. (2012). O novo desenvolvimentismo e apontamentos para uma macroeconomia estruturalista do desenvolvimento. In J. Oreiro, L. Paula, \& F. Basílio (Eds.), Macroeconomia do Desenvolvimento (pp. 15-62). Recife: Editora Universitária UFPE.

Bresser-Pereira, L., Oreiro, J., \& Marconi, N. (2015). Macroeconomia Desenvolvimentista: Teoria e Política Econômica do Novo Desenvolvimentismo. Rio de Janeiro: Elsevier.

Calixtre, A., Biancarelli, A., \& Cintra, M. (2014). Introdução. In A. Calixtre, A. Biancarelli, \& M. Cintra (Eds.), Presente e Futuro do Desenvolvimento Brasileiro (pp. 9-28). Brasilia: IPEA. Retrieved from http://www.ipea.gov.br/portal/index.php?option=com_content\&view=ar ticle\&id $=23279$

Carvalho, L., \& Rugitsky, F. (2015). Growth and distribution in Brazil in the 21st century: revisiting the wage-led versus profit-led debate (Working Papers Department of Economics No. 25). São Paul 
Castro, A. (1990). Consumo de massa e retomada de crescimento. In J. Velloso (Ed.), O desenvolvimento brasileiro da era Geisel ao nosso tempo (pp. 373385). Rio de Janeiro: INAE.

Corrêa, M., \& Feijó, C. (2017). O desenvolvimentismo no Brasil: o debate atual. Análise Econômica, 35(especial), 233-262. https://doi.org/10.22456/21765456.58564

Santos, C., \& Pires, M. (2007). Qual a sensibilidade do investimento privado a aumentos na carga tributaria? Novas estimativas agregadas e desagregadas a partir dos dados das contas nacionais - Referencia 2000(No. 1314). Texto para Discussão. Brasília: IPEA. Retrieved from www.ipea.gov.br/portal. Accessed on February 14 $4^{\text {th }}, 2019$.

Santos, C., \& Pires, M. (2009). Qual a sensibilidade dos investimentos privados a aumentos na carga tributaria brasileira? Uma investigação econométrica. Revista de Economia Política, 29(3), 213-231.

Santos, C., Modenesi, A., Squeff, G., Vasconcelos, L., Mora, M., Fernandes, T., ... Braga, J. (2016). Revisitando a dinâmica trimestral do investimento no Brasil: 1996-2012. Revista de Economia Política, 361), 190-213. https://doi.org/10.1590/0101-31572016v36n01a11

Santos, C. H. M., Orair, R. O., Gobetti, S. W., Ferreira, A. S., Rocha, W. S., Silva, H. L. da, \& Britto, J. M. (2012). Estimativas mensais da formação bruta de capital fixo pública no Brasil (2002-2010). Economia Aplicada, 163), 445473. https://doi.org/10.1590/S1413-80502012000300005

Dutt, A. (1984). Stagnation, income distribution and monopoly power. Cambridge Journal of Economics, 8(1), 25-40. https://doi.org/10.1093/oxfordjournals.cje.a035533

Feijó, C., Lamônica, M. T., \& Bastos, J. C. A. (2016). Why does the investment rate not increase? Capital accumulation and stabilization policy in the 1990s and 2000s in Brazil. Journal of Post Keynesian Economics, 39(4), 539-561. https://doi.org/10.1080/01603477.2016.1148616

Ferrari Filho, F., \& Fonseca, P. D. (2013). Qual desenvolvimentismo? Uma proposição à la wage-led keynesiano-institucionalista. In XLI Encontro Nacional De Economia. Foz do Iguaçu: ANPEC. Available at https://en.anpec.org.br/previous-editions.php?r=encontro-2013. Accessed on February 15 th $^{\text {, }} 2019$. 
Fonseca, P. (2014). Desenvolvimentismo: a Construção do Conceito. In A. Calixtre, A. Biancarelli, \& M. Cintra (Eds.), Presente e Futuro do Desenvolvimento Brasileiro (pp. 29-78). Brasília: IPEA.

Gala, P., \& Araujo, E. (2012). Exchange rates, growth regimes and economic development: Theory and Evidence for Brazil. In XL Encontro Nacional de Economia. Porto de Galinhas. Available at https://en.anpec.org.br/previous-editions.php?r=encontro-2012. Accessed on February $15^{\text {th }}, 2019$.

Hallak Neto, J. (2013). A Distribuição Funcional da Renda e a Economia não observada no âmbito do Sistema de Contas Nacionais do Brasil. Faculdade de Ciências Econômicas, Universidade Federal Rio de Janeiro (UFRJ). Available at http://www.ie.ufrj.br/images/posgraducao/ppge/Joao_Hallak_Neto.pdf. Accessed on February 14 ${ }^{\text {th }}, 2019$.

Hein, E. (2014). Distribution and Growth after Keynes. Distribution and Growth after Keynes. Cheltenham, UK: Edward Elgar. https://doi.org/10.4337/9781783477296

IBGE. (2019). Sistemas de Contas Nacionais Trimestrais. Rio de Janeiro: Instituto Brasileiro de Geografia e Estatística. Retrieved from https://www.ibge.gov.br/estatisticas-novoportal/economicas/contasnacionais/9300-contas-nacionais-trimestrais.html $=\& \mathrm{t}=\mathrm{downloads}$

Kalecki, M. (1937). The principle of increasing risk. Economica, 4(16), 440-447.

Kalecki, M. (1983). Teoria da Dinâmica Econômica: Ensaio sobre as Mudanças Cíclicas e a Longo Prazo da Economia Capitalista. Os Economistas. São Paulo: Abril Cultural.

Kerstenetzky, C. L. (2012). O Estado do bem-estar social na idade da razão. Rio de Janeiro: Campus/Elsevier. https://doi.org/10.1002/ejoc.201200111

Kerstenetzky, C. L. (2016). Consumo social e crescimento redistributivo: Notas para se pensar um modelo de crescimento para o Brasil. Revista de Economia Política, 36(1), 29-45. https://doi.org/10.1590/010131572016v36n01a03

Keynes, J. M. (n.d.). The Collected Writings of John Maynard Keynes, The General Theory of Employment Interest and Money(Vol. VII). London: MacMillan.

Luporini, V., \& Alves, J. (2010). Investimento privado: uma análise empírica para o Brasil. Economia e Sociedade, 19(3), 449-475. https://doi.org/10.1590/S0104-06182010000300002 
Mollo, M. de L. R., \& Amado, A. M. (2015). O debate desenvolvimentista no Brasil: tomando partido. Economia e Sociedade, 24(1), 1-28. https://doi.org/10.1590/1982-3533.2015v24n1art1

Nassif, A., \& Feijó, C. (2013). Liberal versus neo-developmental convention to growth: why has Brazil shown a poor performance since the 1980s? Revista de Economia Política, 33(4), 555-576. https://doi.org/10.1590/s0101-31572013000400001

Oreiro, J. L., Missio, F., \& Jayme, F. G. (2015). Capital accumulation, structural change and real exchange rate in a keynesian-structuralist growth model. Panoeconomicus, 62(2), 237-256. https://doi.org/10.2298/PAN1502237O

Ribeiro, R. S. M., McCombie, J. S. L., \& Lima, G. T. (2017). Some unpleasant currency-devaluation arithmetic in a post Keynesian macromodel. Journal of Post Keynesian Economics, 40(2), 145-167. https://doi.org/10.1080/01603477.2016.1246949

Rowthorn, R. E. (1981). Demand, real wages and economic growth. Thames Papers in Political Economy, 81(3), 1-39.

Sicsú, J., Paula, L., \& Michel, R. (2005). Por que Novo-desenvolvimentismo? In J. Sicsu, L. Paula, \& R. Michel (Eds.), Novo-desenvolvimentismo: um projeto nacional de crescimento com equidade social (pp. 33-51). Barueri: Editora Manole.

Stock, J., \& Watson, M. (1993). A Simple Estimator of Cointegrating Vectors in Higher Order Integrated Systems. Econometrica, 61(4), 783-820.

Taylor, L. (1985). A stagnationist model of economic growth. Cambridge Journal of Economics, 94), 383-403. https://doi.org/10.1093/oxfordjournals.cje.a035588

Torres, D. A. R., \& Resende, M. F. D. C. (2015). Liquidez internacional e formação bruta de capital fixo: evidências econométricas para as economias desenvolvidas e em desenvolvimento. Análise Econômica, 33(63), 7-34. https://doi.org/10.22456/2176-5456.37166 


\section{APPENDIX}

Chart 1. Description of the variables and their sources

\begin{tabular}{|c|c|c|c|c|}
\hline Variable & Proxy & Description & $\begin{array}{c}\text { Original name or series } \\
\text { number }\end{array}$ & Source \\
\hline Investment & $\begin{array}{l}\text { Capital goods } \\
\text { apparent } \\
\text { consumption } \\
\left(C A_{b c}\right)\end{array}$ & $\begin{array}{l}\text { Chain index } \\
(2002 \text { mean } \\
\text { as } 100)^{26}\end{array}$ & $\begin{array}{l}\text { Capital goods apparent } \\
\text { consumption- Chain index } \\
(2002 \text { mean }=100)\end{array}$ & IPEADATA \\
\hline $\begin{array}{l}\text { Profit } \\
\text { share }\end{array}$ & $\begin{array}{c}\text { Share of } \\
\text { gross } \\
\text { operating } \\
\text { excedent to } \\
\text { GDP }(h)\end{array}$ & \multicolumn{3}{|c|}{ Series produced by the authors (see below) } \\
\hline $\begin{array}{c}\text { Rate of } \\
\text { capacity } \\
\text { utilization }\end{array}$ & \multicolumn{2}{|c|}{$\begin{array}{l}\text { Capacity utilization in } \\
\text { general industry }(\mathrm{u})\end{array}$} & $\begin{array}{l}\text { Installed capacity } \\
\text { utilization in the industry }\end{array}$ & $\mathrm{CNI}$ \\
\hline $\begin{array}{l}\text { Real } \\
\text { exchange } \\
\text { rate }\end{array}$ & $\begin{array}{l}\text { Effective Real } \\
\text { Exchange } \\
\text { rate }(e) \\
\text { (Dollar) }\end{array}$ & $\begin{array}{c}\text { Index } \\
\text { number: } \\
\text { June } \\
\text { 1994=100- }\end{array}$ & Series number 11753 & $\begin{array}{c}\text { Brazilian } \\
\text { Central } \\
\text { Bank } \\
\text { (Bacen) }\end{array}$ \\
\hline $\begin{array}{l}\text { Real } \\
\text { interest } \\
\text { rate }\end{array}$ & $\begin{array}{l}\text { Real Selic } \\
\text { rate }(r)\end{array}$ & $\begin{array}{r}\text { Series proc } \\
\text { Interest rate } \\
\text { Inflation by } \\
\text { expectati }\end{array}$ & $\begin{array}{l}\text { uced by the authors (see } \\
\text { below). } \\
\text { Swap-DI: serie no. } 7827 \\
\text { consumer inflation (IPCA) } \\
\text { naccumulated over } 12 \\
\text { months. }\end{array}$ & $\begin{array}{c}\text { Brazilian } \\
\text { Central } \\
\text { Bank } \\
\text { (Bacen) }\end{array}$ \\
\hline $\begin{array}{l}\text { Public } \\
\text { investment }\end{array}$ & $\begin{array}{c}\text { Gross fixed } \\
\text { capital } \\
\text { formation by } \\
\text { public } \\
\text { administration } \\
\quad\left(i_{p}\right)\end{array}$ & $\begin{array}{l}\text { Dos Santos } \\
\text { fixed car }\end{array}$ & $\begin{array}{l}\text { et al (2016) for the gross } \\
\text { ital formation by public } \\
\text { administration. }\end{array}$ & $\begin{array}{c}\text { Original } \\
\text { data from } \\
\text { Dos } \\
\text { Santos et } \\
\text { al (2011) }\end{array}$ \\
\hline
\end{tabular}

The proxy of the share of profits to income was obtained by the ratio of the gross operating surplus to GDP from the National Accounts. To increase the frequency of this variable, which is only available for each year, we employed parts of the methodology developed in Bastos $(2012)^{27}$, in which the author transforms

\footnotetext{
${ }^{26}$ For the methodology of the index: http://www.IpeaData.gov.br/doc/cc17_nt02_indicadores.pdf ${ }^{27}$ Bastos (2012) methodology is divided in two parts: estimation of the high frequency series based on PME (Monthly Employment Survey) and harmonization of this high frequency series with the of National Accounts aggregates. Our procedure considered only the compatibility of the PME series and the annual series of National Accounts in the following way: we ensured that the average annual share of profits estimated from PME is identical to the share of profits found in the National Accounts:
} 
the annual data of the National Accounts to quarterly data using the Monthly Employment Survey (PME). The author points out that the same methodology can be employed to transform the annual data into month data. The monthly GDP calculated by the Brazilian Central Bank, is used as the denominator. The data for 2012 and 2013 were estimated following Hallak Neto (2013).

The real interest is ex-ante, calculated taking into account the expectation of inflation,

$r_{-}($ex-ante $)=\left[(1+\right.$ s_DI $\left./ 100) /\left(1+\theta \_e p / 100\right)\right] 1 * 100$

where

s_DI = swap-DI 360; average of the period; (Bacen-7827)

$\theta \_$ep $=$inflation expectation twelve months ahead using the average of the medians (Bacen - market expectation) $^{28}$

$$
\pi_{i, a}=\left(\pi_{i, a}^{p m e} * w_{a}^{s c n}\right) / \overline{\pi_{a}^{p m e}}
$$

Where:

$\pi_{i, a}=$ share of profits to GDP in the month $i$ and in the year $a ; \pi_{i, a}^{p m e}=$ share of profits to GDP resulting by step one in the month $i$ and in the year $a ; \pi_{a}^{s c n}=$ share of profits to GDP by National Accounts in year $a ; \overline{\pi_{a}^{p m e}}=$ average share of profits to GDP resulting by step one in the year $a$. ${ }^{28}$ Because of the lack of data for July 1999 until November 2001, a proxy for these two years was constructed using IPCA 12 months ahead instead of its expectation. 
Table A1. Unit root tests

\begin{tabular}{|c|c|c|c|c|c|}
\hline VARIABLES & $A D F-S C I$ & ADF - ACI & ADF - HQCI & $\begin{array}{c}\text { PP -NW } \\
\text { Bandwidth }\end{array}$ & $\begin{array}{l}\text { KPSS - NW } \\
\text { Bandwidth }\end{array}$ \\
\hline \multicolumn{6}{|c|}{ Level } \\
\hline$I$ & $\begin{array}{l}\text { It has unit } \\
\text { root }\end{array}$ & $\begin{array}{l}\text { It has unit } \\
\text { root }\end{array}$ & $\begin{array}{l}\text { It has unit } \\
\text { root }\end{array}$ & It has unit root & $\begin{array}{l}\text { It has unit } \\
\text { root }(1 \%)\end{array}$ \\
\hline$u$ & $\begin{array}{c}\text { no unit } \\
\text { root }(1 \%)\end{array}$ & $\begin{array}{l}\text { no unit root } \\
(1 \%)\end{array}$ & $\begin{array}{c}\text { no unit root } \\
(1 \%)\end{array}$ & $\begin{array}{l}\text { No unit root } \\
(1 \%)\end{array}$ & No unit root \\
\hline $\boldsymbol{h}$ & $\begin{array}{c}\text { No unit } \\
\text { root }(1 \%)\end{array}$ & $\begin{array}{l}\text { No unit root } \\
(1 \%)\end{array}$ & $\begin{array}{l}\text { No unit root } \\
(1 \%)\end{array}$ & $\begin{array}{l}\text { No unit root } \\
(1 \%)\end{array}$ & No unit root \\
\hline Ip & $\begin{array}{l}\text { It has unit } \\
\text { root }\end{array}$ & $\begin{array}{l}\text { It has unit } \\
\text { root }\end{array}$ & $\begin{array}{l}\text { It has unit } \\
\text { root }\end{array}$ & It has unit root & $\begin{array}{l}\text { It has unit } \\
\text { root }(1 \%)\end{array}$ \\
\hline e & $\begin{array}{c}\text { It has unit } \\
\text { root }\end{array}$ & $\begin{array}{c}\text { It has unit } \\
\text { root }\end{array}$ & $\begin{array}{c}\text { It has unit } \\
\text { root }\end{array}$ & It has unit root & $\begin{array}{l}\text { It has unit } \\
\text { root }(1 \%)\end{array}$ \\
\hline$e^{2}$ & $\begin{array}{c}\text { It has unit } \\
\text { root }\end{array}$ & $\begin{array}{c}\text { It has unit } \\
\text { root }\end{array}$ & $\begin{array}{c}\text { It has unit } \\
\text { root }\end{array}$ & It has unit root & $\begin{array}{l}\text { It has unit } \\
\text { root }(1 \%)\end{array}$ \\
\hline$r$ & $\begin{array}{c}\text { No unit } \\
\text { root }(1 \%)\end{array}$ & $\begin{array}{l}\text { No unit root } \\
(5 \%)\end{array}$ & $\begin{array}{l}\text { No unit root } \\
(5 \%)\end{array}$ & $\begin{array}{l}\text { No unit root } \\
(5 \%)\end{array}$ & No unit root \\
\hline \multicolumn{6}{|c|}{ FIRST DIFFERENCE } \\
\hline$I$ & $\begin{array}{c}\text { No unit } \\
\text { root }(1 \%)\end{array}$ & $\begin{array}{l}\text { No unit root } \\
(1 \%)\end{array}$ & $\begin{array}{l}\text { No unit root } \\
(1 \%)\end{array}$ & $\begin{array}{l}\text { No unit root } \\
(1 \%)\end{array}$ & No unit root \\
\hline Ip & $\begin{array}{c}\text { No unit } \\
\text { root }(1 \%)\end{array}$ & $\begin{array}{l}\text { No unit root } \\
(1 \%)\end{array}$ & $\begin{array}{l}\text { No unit root } \\
(1 \%)\end{array}$ & $\begin{array}{l}\text { No unit root } \\
(1 \%)\end{array}$ & No unit root \\
\hline e & $\begin{array}{c}\text { No unit } \\
\text { root }(1 \%)\end{array}$ & $\begin{array}{l}\text { No unit root } \\
(1 \%)\end{array}$ & $\begin{array}{l}\text { No unit root } \\
(1 \%)\end{array}$ & $\begin{array}{l}\text { No unit root } \\
(1 \%)\end{array}$ & No unit root \\
\hline$e^{2}$ & $\begin{array}{l}\text { No unit } \\
\text { root (1\%) }\end{array}$ & $\begin{array}{c}\text { No unit root } \\
(1 \%)\end{array}$ & $\begin{array}{c}\text { No unit root } \\
(1 \%)\end{array}$ & $\begin{array}{c}\text { No unit root } \\
(1 \%)\end{array}$ & $\begin{array}{l}\text { It has unit } \\
\text { root }(1 \%)\end{array}$ \\
\hline
\end{tabular}


REGRESSION TESTS: MODEL 1

Table A2. Results of residues test

\begin{tabular}{|c|c|c|c|}
\hline $\begin{array}{c}\text { Bera-Jarque } \\
4,1\end{array}$ & $\begin{array}{c}\text { Prob. } \\
0,13 \\
\end{array}$ & & \\
\hline \multicolumn{3}{|c|}{ Breusch-Godfrey Serial Correlation LM Test: } & \\
\hline F-statistic & 0,57 & Prob. $F(1,169)$ & 0,45 \\
\hline Obs*R-squared & 0,53 & Prob. Chi-Square(1) & 0,47 \\
\hline F-statistic & 0,62 & Prob. F(2,168) & 0,54 \\
\hline Obs*R-squared & 1,21 & Prob. Chi-Square(2) & 0,54 \\
\hline F-statistic & 1,81 & Prob. $F(3,167)$ & 0,148 \\
\hline Obs*R-squared & 5,42 & Prob. Chi-Square(3) & 0,14 \\
\hline F-statistic & 2,30 & Prob. $F(4,166)$ & 0,06 \\
\hline Obs*R-squared & 9,10 & Prob. Chi-Square(4) & 0,059 \\
\hline F-statistic & 2,03 & Prob. $F(5,165)$ & 0,077 \\
\hline Obs ${ }^{*}$-squared & 10,04 & Prob. Chi-Square(5) & 0,07 \\
\hline F-statistic & 1,68 & Prob. F(6,164) & 0,13 \\
\hline Obs*R-squared & 10,04 & Prob. Chi-Square(6) & 0,12 \\
\hline F-statistic & 1,43 & Prob. F(7,163) & 0,19 \\
\hline Obs ${ }^{*}$-squared & 10,04 & Prob. Chi-Square(7) & 0,19 \\
\hline F-statistic & 1,25 & Prob. F(8,162) & 0,27 \\
\hline Obs*R-squared & 10,09 & Prob. Chi-Square(8) & 0,26 \\
\hline F-statistic & 1,41 & Prob. F(9,161) & 0,19 \\
\hline Obs*R-squared & 12,67 & Prob. Chi-Square(9) & 0,18 \\
\hline F-statistic & 1,34 & Prob. $F(10,160)$ & 0,21 \\
\hline Obs*R-squared & 13,41 & Prob. Chi-Square(10) & 0,20 \\
\hline F-statistic & 1,50 & Prob. F(11,159) & 0,14 \\
\hline Obs ${ }^{*}$ R-squared & 16,31 & Prob. Chi-Square(11) & 0,13 \\
\hline F-statistic & 1,65 & Prob. F(12,158) & 0,08 \\
\hline Obs*R-squared & 19,36 & Prob. Chi-Square(12) & 0,08 \\
\hline \multicolumn{4}{|c|}{ Heteroskedasticity Test: Breusch-Pagan-Godfrey } \\
\hline F-statistic & 0,20 & Prob. $F(2,171)$ & 0,82 \\
\hline \multirow{2}{*}{$\begin{array}{c}\text { Obs*R-squared } \\
\text { Scaled explained } \\
\text { SS }\end{array}$} & 0,40 & Prob. Chi-Square(2) & 0,82 \\
\hline & 0,52 & Prob. Chi-Square(2) & 0,77 \\
\hline
\end{tabular}




\section{TESTS OF THE COINTEGRATION MODEL}

Table A3. Cointegration test - Phillips-Ouliaris - Model 2

Specification: Logl Loge Loge ${ }^{2} \mathrm{c} @$ @REND h u r

Cointegrating equation deterministics: c @TREND h u r

Null hypothesis: Series are not cointegrated

Long-run variance estimate (Bartlett kernel, Newey-West fixed bandwidth $=5.0000$ )

No d.f. adjustment for variances

\begin{tabular}{lcc}
\hline & Value & Prob. $^{*}$ \\
Phillips-Ouliaris tau-statistic & $-8,170327$ & 0,00 \\
Phillips-Ouliaris z-statistic & $-102,1291$ & 0,00 \\
${ }^{*}$ MacKinnon (1996) p-values. & & \\
\hline
\end{tabular}

Table A4. Cointegration test - Phillips-Ouliaris - Model 3

Specification: Log CAbc Log e Log $\mathrm{e}^{2} \log$ Ip c u h r Trend

Cointegrating equation deterministics: c @TREND u h r

Null hypothesis: Series are not cointegrated

Long-run variance estimate (Bartlett kernel, Newey-West fixed bandwidth $=5.0000$ )

No d.f. adjustment for variances

\begin{tabular}{lcc} 
& Value & Prob. $^{*}$ \\
\hline Phillips-Ouliaris tau-statistic & $-8,14$ & 0,00 \\
Phillips-Ouliaris z-statistic & $-100,89$ & 0,00 \\
\hline
\end{tabular}

Table A5. Cointegration test - Phillips-Ouliaris - Model 4

Specification: Log I Log e Log e $\log$ Ip c u h r

Cointegrating equation deterministics: $\mathrm{c} u \mathrm{~h} \mathrm{r}$

Null hypothesis: Series are not cointegrated

Long-run variance estimate (Bartlett kernel, Newey-West fixed bandwidth $=5.0000$ )

No d.f. adjustment for variances

Phillips-Ouliaris tau-statistic

Value $\quad$ Prob. $^{*}$

Phillips-Ouliaris z-statistic

$-8,181420 \quad 0,00$

*MacKinnon (1996) p-values. 